\title{
SISTEM INFORMASI REKAM MEDIS PADA PRAKTEK DOKTER HEWAN NURCAHYO SAKSONO BERBASIS WEB
}

\author{
Eva Rianti ${ }^{1}$, Melda Agarina ${ }^{2}$ \\ ${ }^{1,2}$ Institut Informatika dan Bisnis Darmajaya \\ evariantiindo@gmail.com ${ }^{1}$,agharina@darmajaya.ac.id ${ }^{2}$
}

\begin{abstract}
A medical record is a file containing records and documents about the patient's identity, examination, treatment, actions and other services that have been provided to the patient on health care facilities. The problems that occur in the veterinarian Nurcahyo Saksono is the management of medical data that is less effective and efficient. The development method with Prototype method, while the program was built using PHP, MySQL and Bootstrap. The results of the medical record information system in the practice of Nurcahyo Saksono Veterinary web-based can facilitate the search for data, examination documents, patient data, medical record data or report data per period because it is integrated and stored into a database and can be accessed anywhere or anytime. With a web-based medical record information system about Nurcahyo Saksono's Veterinarian practices, he can speed up the administration process in terms of registering medical records, scheduling practices, and consulting pet owners that can be online without having to come.
\end{abstract}

Keywords: Medical Record Information System; Veterinarian; Prototype; Website.

\begin{abstract}
Abstrak
Rekam medis adalah berkas yang berisi catatan dan dokumen tentang identitas pasien, pemeriksaan, pengobatan, tindakan dan pelayanan lain yang telah diberikan kepada pasien pada sarana pelayanan kesehatan. Permasalahan yang terjadi di Dokter Hewan Nurcahyo Saksono yaitu pengelolaan data medis yang kurang efektif dan efisien. Metode pengembangan dalam mengembangkan sistem informasi menggunakan metode Prototype, sedangkan program yang dibangun menggunakan $P H P, M y S Q L$ dan Bootstrap. Hasil dari sistem informasi rekam medis pada praktek Dokter Hewan Nurcahyo Saksono berbasis web diantaranya dapat memudahkan pencarian data, dokumen pemeriksaan, data pasien, data rekam medis ataupun data laporan per periode karena sudah terintegrasi dan tersimpan kedalam database dan dapat diakses dimanapun atau kapanpun. Dengan adanya sistem informasi rekam medis pada praktek Dokter Hewan Nurcahyo Saksono berbasis web dapat mempercepat proses administrasi dalam hal pendaftaran rekam medis, penjadwalan praktek dan konsultasi pemilik hewan yang dapat dilakukan secara online tanpa harus datang.
\end{abstract}

Kata kunci: Sistem Informasi Rekam Medis; Dokter Hewan; Prototype; Website

\section{PENDAHULUAN}

Berkembangnya teknologi saat ini membuat para pelaku bisnis semakin memanfaatkan media teknologi sebagai suatu sarana untuk mengabungkan bisnis dibidang pelayanan kesehatan, khususnya di bidang jasa pelayanan kesehatan hewan, seperti kucing dan anjing.

Dokter Hewan Nurcahyo Saksono adalah pelaku bisnis dibidang jasa pelayanan kesehatan. Dokter hewan nurcahyo saksono berada di Bandar lampung yaitu dijalan Dokter warsito no.73 kupang kota Bandar lampung, kec. Teluk betung barat, dokter hewan nurcahyo saksono membuka praktiknya setiap hari yaitu senin sampai minggu 
dengan jam praktik jam 7:30 sampai jam 09:00 lalu membuka kembali jam 16:00 sampai dengan 19:00 WIB.

Saat ini, sistem pelayanan yang berjalan dalam hal administrasi masih mengharuskan pasien atau pemilik hewan datang untuk mendaftar, megisi formulir pendaftaran dan mengantri sehingga harus menunggu lama. selain itu, jadwal konsultasi dokter yang terbilang cukup singkat yaitu dari jam 07:00 sampai dengan 09:00 dan dilanjut lagi dengan jam 16:00 sampai dengan 19:00 dan dibandingkan jumlah pasien yang mencapai 15 perhari membuat pihak administrasi kesulitan dalam mengelola jadwal konsultasi sehingga membuat pasien atau pemilik hewan mengeluh terhadap pelayanan yang kurang maksimal.

Berdasarkan permasalahan yang telah dijelaskan diatas diperlukan adanya suatu sistem informasi yang dapat membantu pihak Dokter Hewan Nurcahyo Saksono dan pasien pemilik hewan peliharaan dalam hal admisnistrasi meliputi pendaftaran rekam medis, penjadwalan praktek dan konsultasi, sehingga dibuat sebuah sistem informasi rekam medis berbasis web.

\section{KERANGKA TEORI}

\subsection{Sistem}

Pada dasarnya, sistem adalah sekumpulan elemen yang saling terkait atau terpadu yang dimaksudkan untuk mencapai suatu tujuan. Sebagai gambaran, jika sebuah sistem terdapat elemen yang tidak memberikan manfaatdalam mencapai tujuan yang sama, maka elemen tersebut dapat dipastikan bukanlah bagian dari sistem (Kadir, 2014).

\subsection{Informasi}

McFadden, dan kawan-kawan mendefinisikan informasi sebagai data yang telah diproses sedemikian rupa sehingga meningkatkan pengetahuan seseorang yang menggunakan data tersebut. Shannon dan Weaver, dua orang insinyur listrik melakukan pendektan secara matematis untuk mendefinisikan informasi (Kroenke). Menurut mereka, informasi adalah jumlah ketidakpasian yang dikurangi ketika sebuah pesan diterima. Artinya, dengan adanya informasi, tingkat kepastian menjadi meningkat. Menurut Davis, informasi adalah data yang telah diolah menjadi sebuah bentuk yang berarti bagi penerimanya dan bermanfaat dalam pengambilan keputusan saat ini atau saat mendatang (Kadir, 2014).

\subsection{Sistem Informasi}

Sesungguhnya yang dimaksud sistem informasi tidak harus melibatkan komputer.Sistem informasi yang menggunakan komputer biasa disebut sistem informasi berbasis komputer (Computer Based Information System atau CBIS). Dalam praktik, istilah sistem informasi lebih sering dipakai tanpa embel-embel berbasis komputer, walaupun dalam kenyataannya komputer merupakan bagian yang penting.

\section{Rekam Medis}

Peraturan Menteri Kesehatan Republik Indonesia No. 269/MENKES/PER/III/2008 rekam medis adalah berkas yang berisi catatan dan dokumen tentang identitas pasien, pemeriksaan, pengobatan, tindakan dan pelayanan lain yang telah diberikan kepada pasien pada sarana pelayanan kesehatan. Berdasarkan pengertian diatas maka rekam medis memiliki manfaat sebagai berikut:

1) Pengobatan Pasien

Rekam medis bermanfaat sebagai dasar dan juga petunjuk untuk membuat rencana, menganalisa penyakit 
dan juga merancang pengobatan, perawatan dan juga tindakan- tindakan medis apa yang harus diberikan kepada pasien.

2) Peningkatan Kualitas Pelayanan

Membuat rekam medis bagi setiap penyelenggaraan praktik ilmu kedokteran dengan jelas dan juga lengkap akan berpengaruh pada peningkatan kualitas pelayanan serta melindungi tenaga medis dan untuk pencapaian kesehatan masyarakat yang optimal.

3) Pendidikan dan Penelitian Rekam medis yang merupakan data dan informasi perkembangan kronologis penyakit, pelayanan medis, pengobatan dan tindakan medis, bermanfaat menjadi bahan informasi untuk perkembangan pengajaran dan penelitian di bidang profesi kedokteran dan kedokteran gigi.

4) Pembiayaan Berkas rekam medis dapat dijadikan petunjuk dan bahan untuk menetapkan pembiayaan dalam pelayanan kesehatan pada sarana kesehatan. Catatan tersebut.

\section{METODE PENELITIAN}

Metode pengembangan sistem yang digunakan dalam penelitian ini adalah Metode Prototype. Metodologi ini memiliki beberapa tahapan penting yang harus dilakukan dalam merancang dan membangun sistem rekam medis pada praktek Dokter Hewan Nurcahyo Saksono. Adapun proses tahapan yang akan digunakan antara lain sebagai berikut:

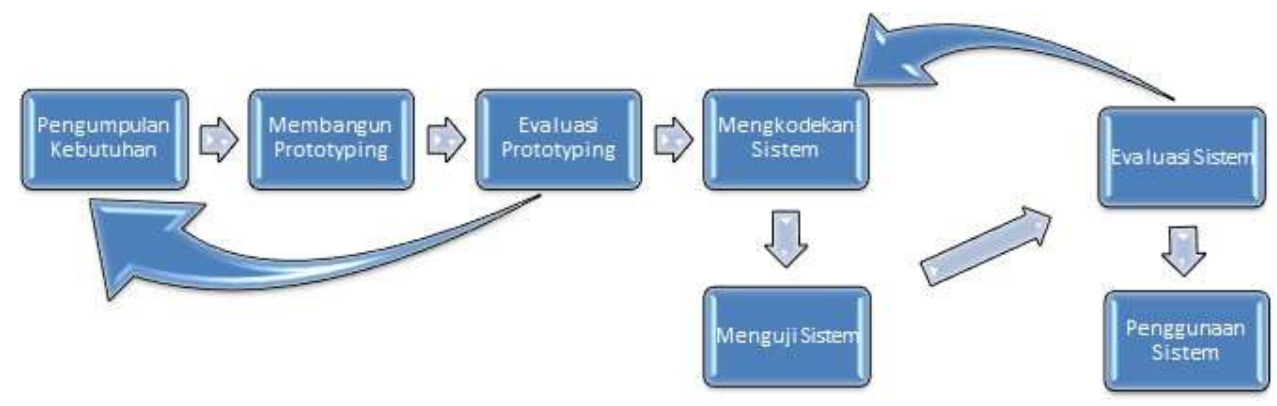

Gambar 1. Model Prototype. Raymond McLeod (Sidik : 2015)

Metode pengumpulan data dalam penelitian ini dilakukan dengan cara observasi ke lapangan, wawancara dengan informan, dan studi pustaka untuk mendapatkan informasi yang sesuai dengan penelitian. Data yang diperoleh dari pengumpulan data tersebut kemudian dianalisis. Dari analisis sistem yang sedang berjalan saat ini, maka didapatlah analisis suatu permasalahan yang kemudian dari permasalahan tersebut akan diusulkan sistem yang baru.

\section{HASIL DAN PEMBAHASAN}

Pada tahap ini akan di jelaskan tentang implementasi program yang telah dirancang sesuai dengan analisis dan perancangan yang telah dilakukan, antara lain: 


\section{Halaman Form Registrasi}

Rancangan form registrasi adalah tahap awal untuk mendapatkan username dan password sebelum melakukan login. Halaman form registrasi diperuntukan untuk pasien baru yang belum memiliki akun/ belum melakukan registrasi di website yang telah dibuat.

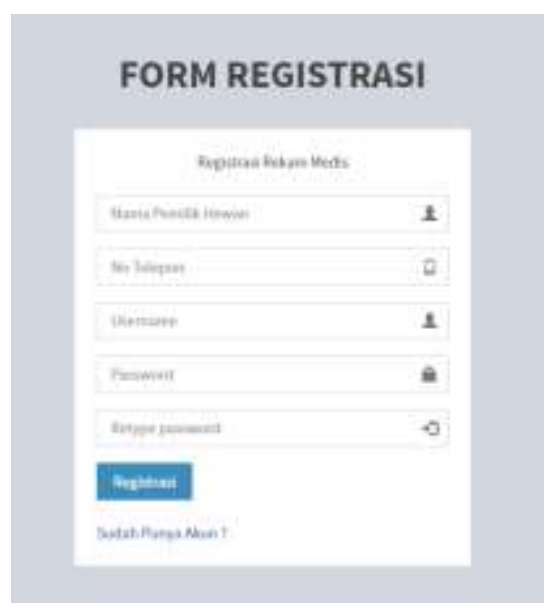

Gambar 2. Halaman Form Registrasi

\section{Halaman Form Login}

Halaman form login ini untuk user masuk ke halaman session user. Pada halaman seperti ditunjukkan pada Gambar 3 user melakukan login dengan memasukkan username dan password sesuai dengan level Admin atau Member untuk mengakses halaman utama.

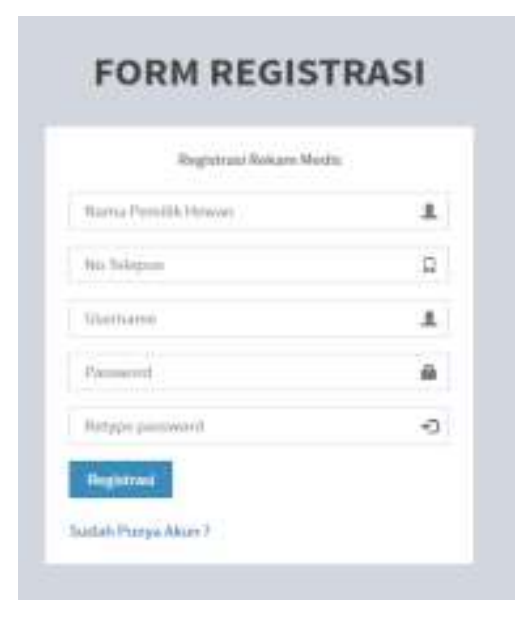

Gambar 3. Halaman Form Login

\section{Halaman Utama}

Halaman ini ditujukan kepada semua user yang memiliki akun login meliputi: Staff Administrasi, Dokter dan Pemilik Hewan Halaman Utama pada sistem informasi rekam medis pada praktek dokter hewan Nurcahyo Saksono berbasis web dapat dilihat pada Gambar 4. 


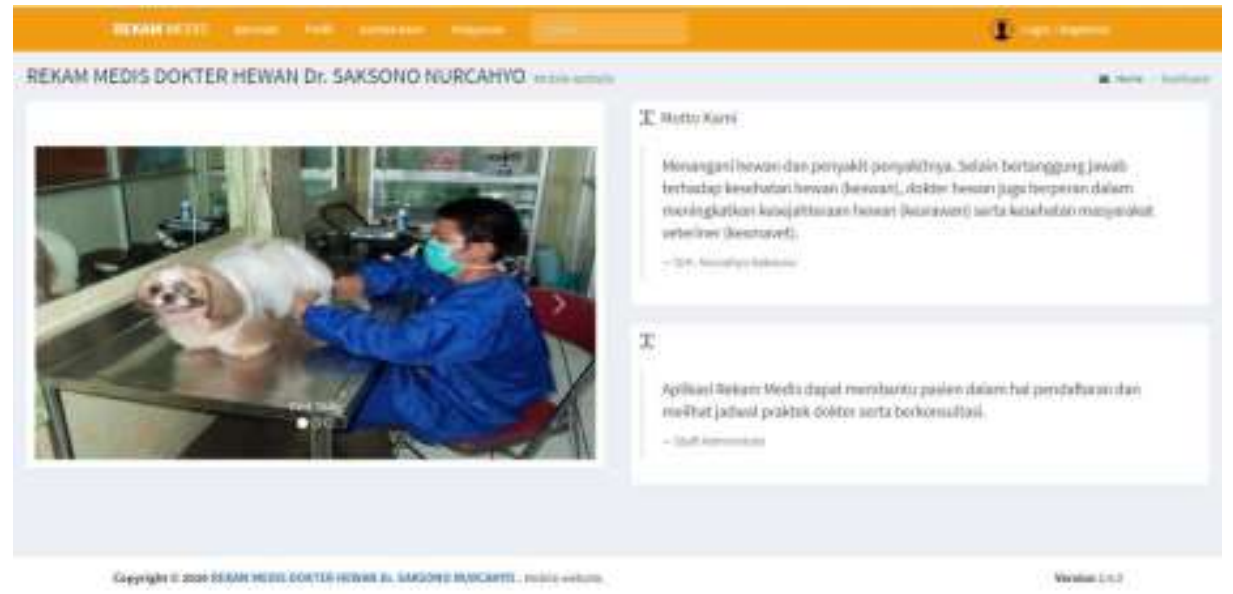

Gambar 4. Halaman Utama

\section{Halaman Pelayanan}

Pada halaman ini menampilkan informasi tentang jenis pelayanan yang ada di tempat praktek dokter hewan Nurcahyo Saksono.

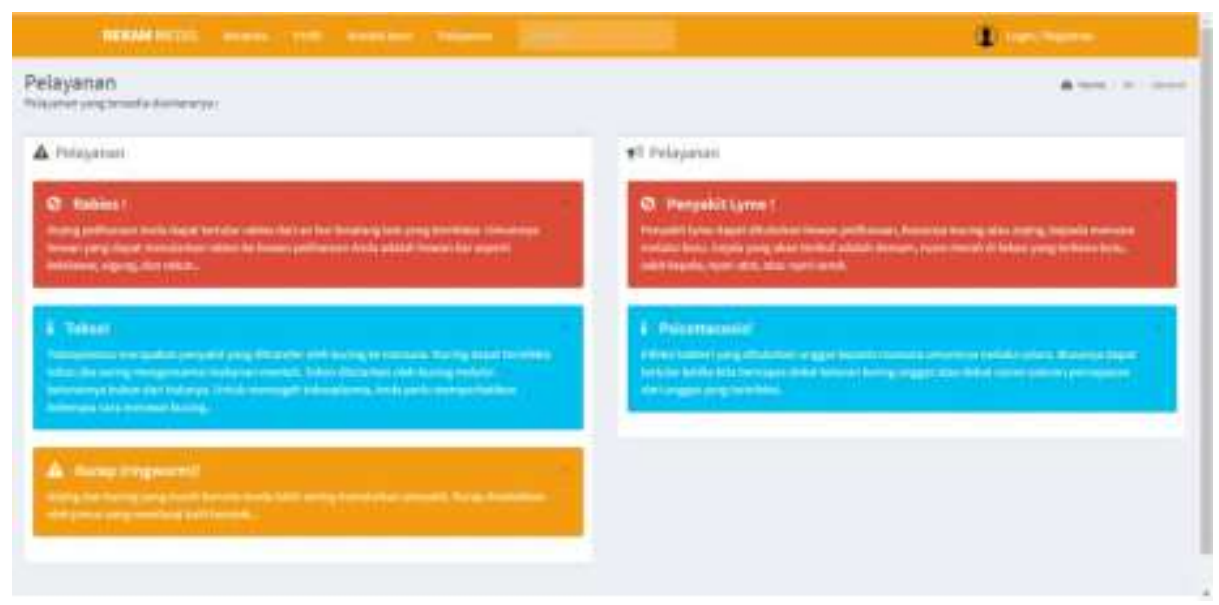

Gambar 5. Halaman Pelayanan

\section{Halaman Staff Administrasi}

Halaman utama staff administrasi setelah melakukan login. Tampilan halaman staff administrasi dapat dilihat pada gambar 6 . 


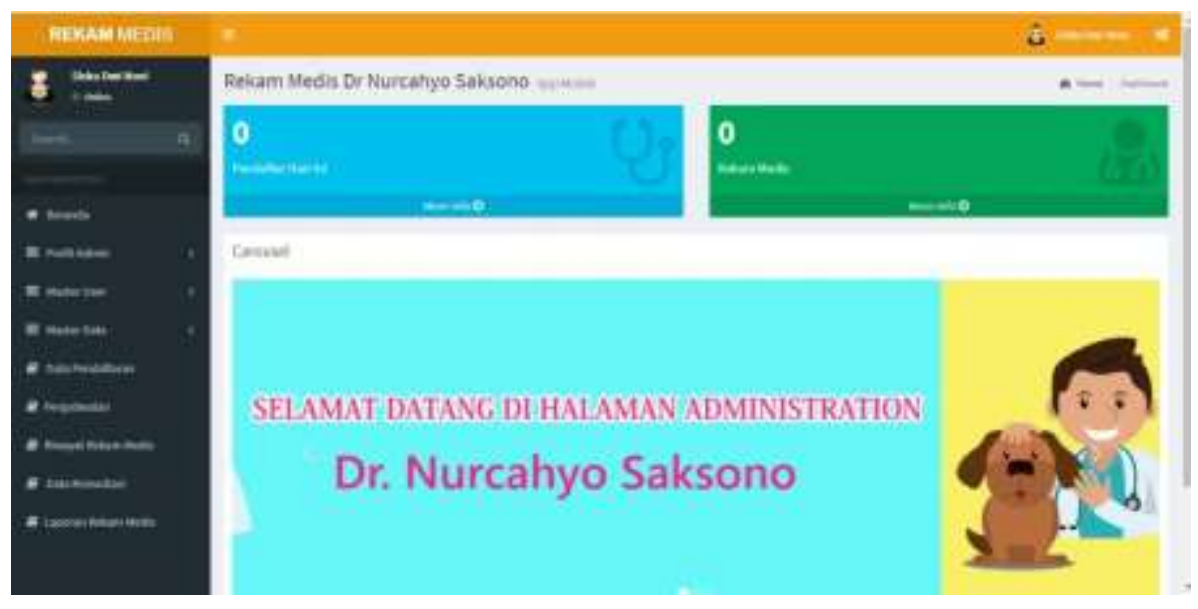

Gambar 6. Halaman Staff Administrasi

\section{Halaman Data Jenis Pelayanan}

Halaman data jenis pelayanan dikelola staff administrasi, pada halaman ini menampilkan jenis pelayanan yang ada di website dokter Nurcahyo Saksono. Tampilan data jenis pelayanan dilihat pada Gambar 7.

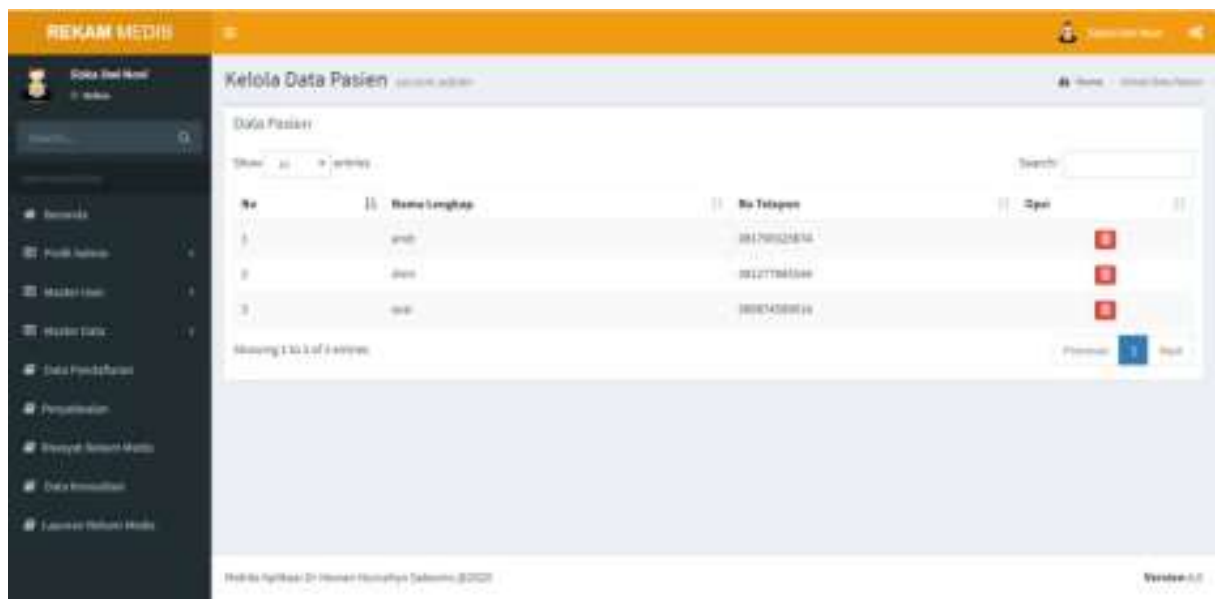

Gambar 7. Halaman Data Jenis Pelayanan

\section{Halaman Data Pendaftaran}

Rancangan halaman pendaftaran adalah halaman bagi staff administrasi dalam mengelola data pendaftaran Halaman data pendaftaran dikelola staff administrasi dapat dilihat pada Gambar 8 . 


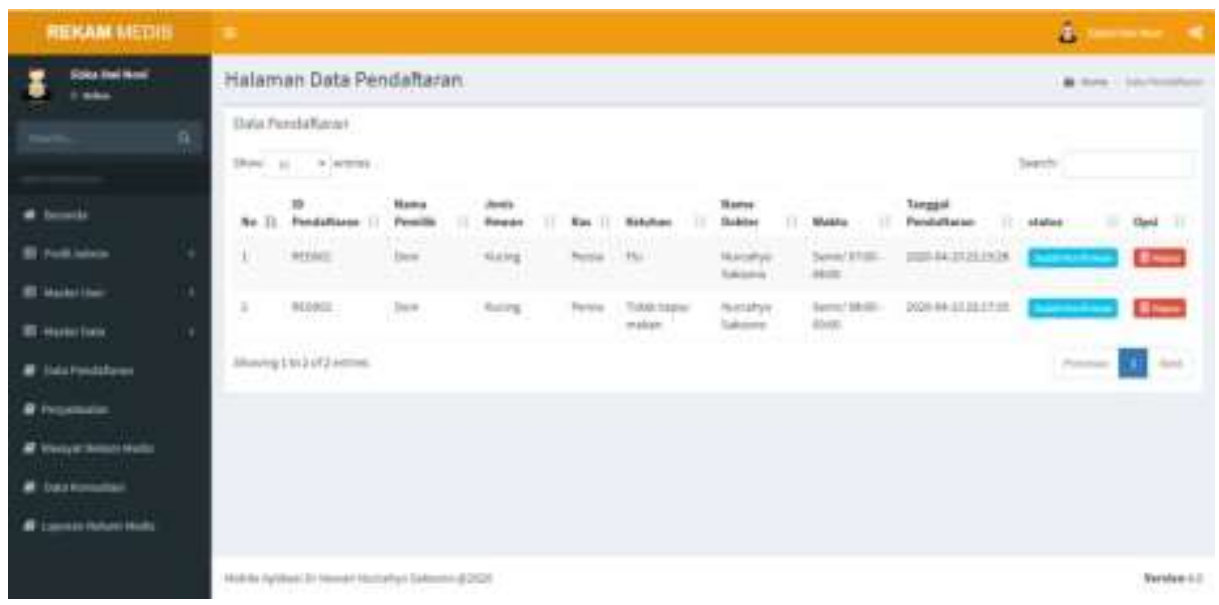

Gambar 8. Halaman Data Pendaftaran

\section{Halaman Data Penjadwalan}

Halaman data penjadwalan dikelola staff administrasi untuk menampilkan data-data pasien yang telah diberi jadwal sesuai jadwal dokter. Tampilan data penjadwalan dilihat pada Gambar 9.

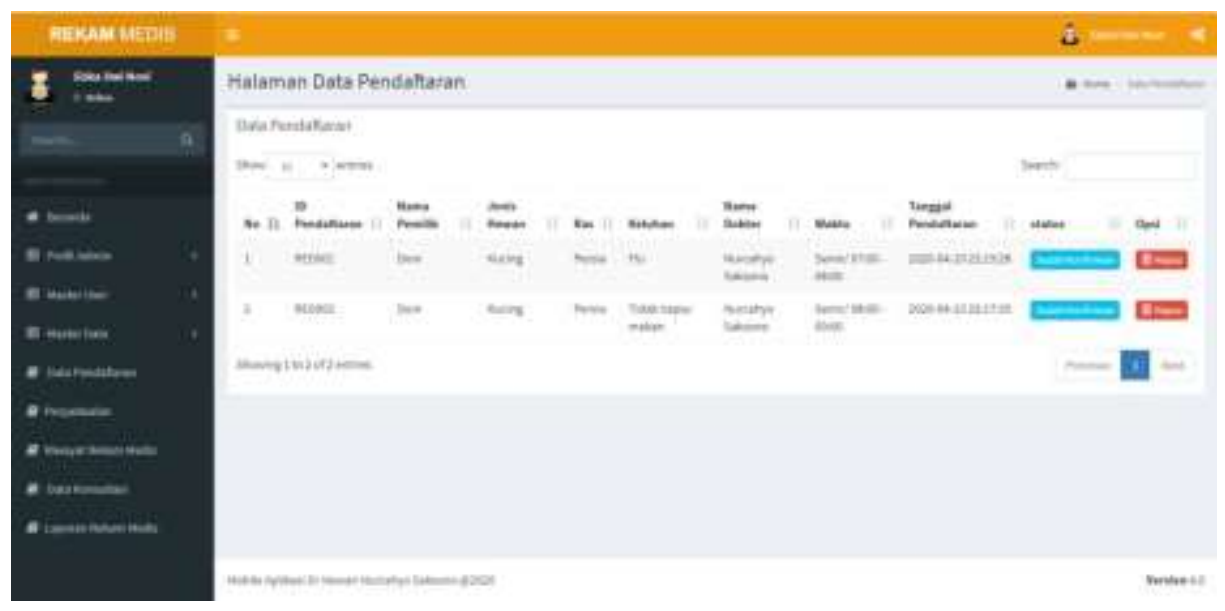

Gambar 9. Halaman Data Penjadwalan

\section{Halaman Penjadwalan Dokter}

Halaman penjadwalan dokter guna melihat data jadwal dokter. Tampilan halaman penjadwalan dokter dapat dilihat pada Gambar 10. 


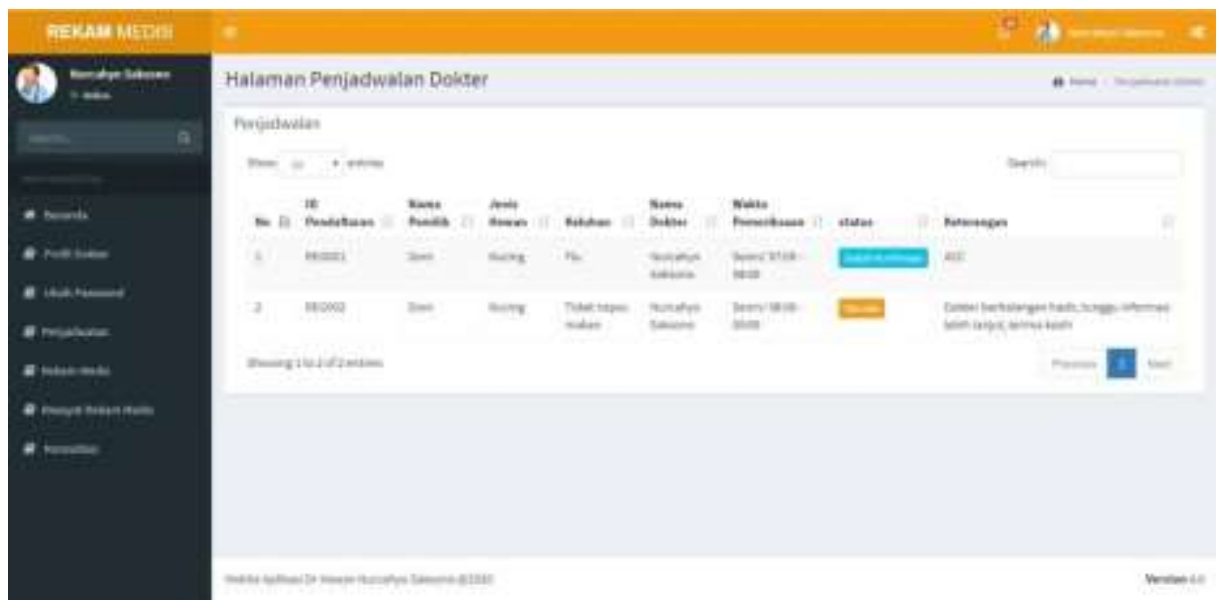

Gambar 10. Halaman Penjadwalan Dokter

\section{Halaman Rekam Medis Dokter}

Rancangan form input rekam medis adalah halaman form input rekam medis yang digunakan oleh staff administrasi. Halaman rekam medis dokter guna melakukan pemeriksaan rekam medis. Tampilan halaman rekam medis dokter dapat dilihat pada Gambar 11.

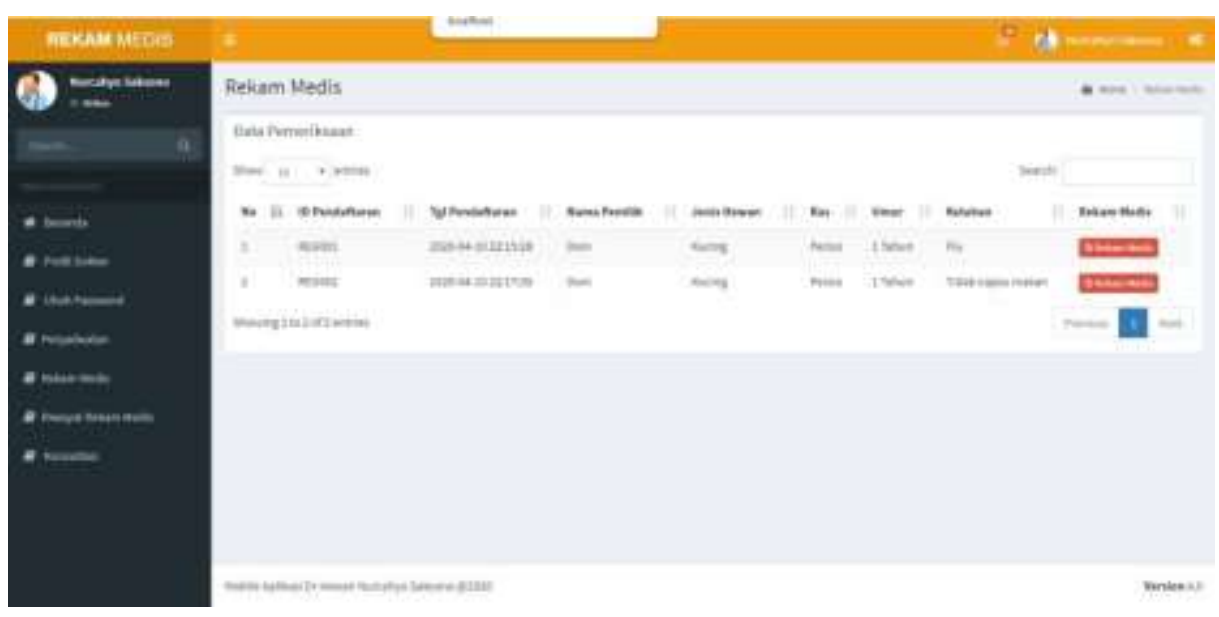

Gambar 11. Halaman Rekam Medis Dokter

\section{Halaman Riwayat Rekam Medis Dokter}

Halaman riwayat rekam medis dokter guna melihat riwayat rekam medis pasien. Tampilan halaman riwayat rekam medis dokter dapat dilihat pada Gambar 12. 


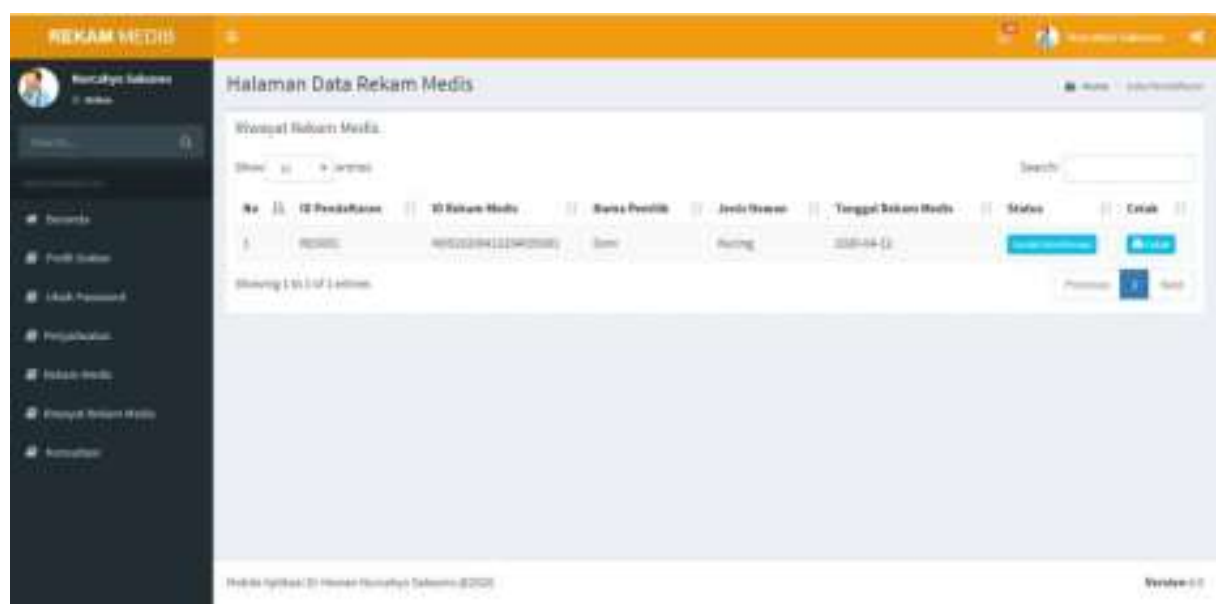

Gambar 12. Halaman Riwayat Rekam Medis Dokter

\section{Halaman Konsultasi Dokter}

Halaman konsultasi dokter guna melihat data konsultasi pasien. Tampilan halaman konsultasi dokter dapat dilihat pada Gambar 13.

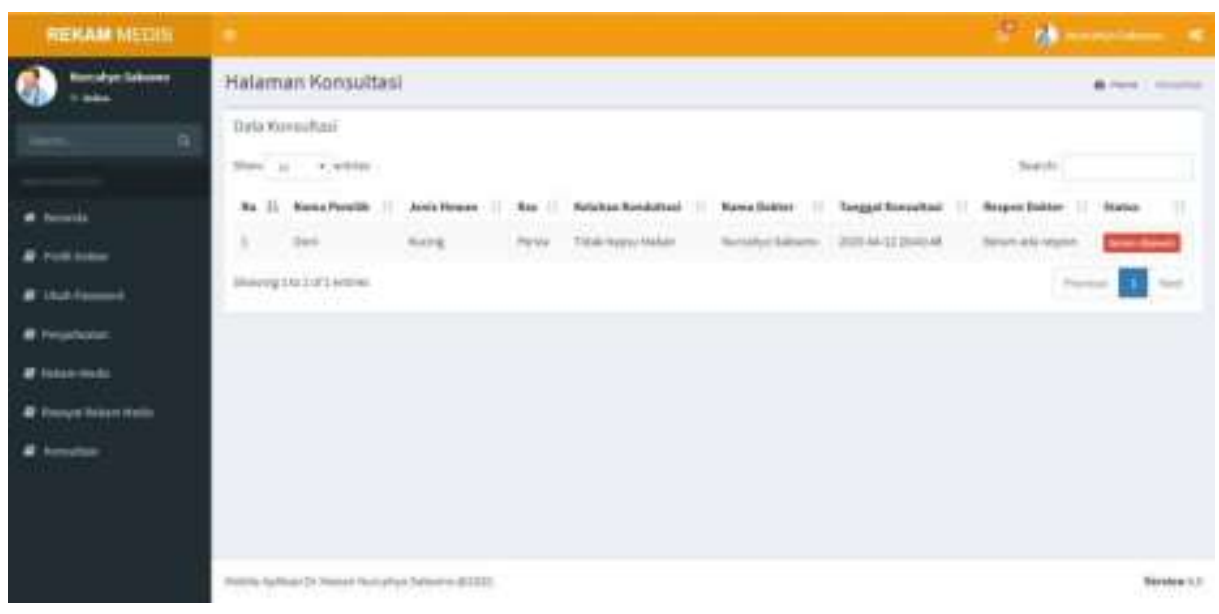

Gambar 13. Halaman Konsultasi Dokter

\section{Pengujian Sistem}

Pengujian salah satu bagian terpenting dalam pembuatan program. Pengujian dilakukan untuk menjamin kualitas dan juga mengetahui kelemahan dari program tersebut. Tujuan dari pengujian perangkat lunak ini adalah untuk menjamin bahwa perangkat lunak yang dibangun memiliki kualitas yang handal yaitu mampu mempresentasikan kajian pokok dari spesifikasi, analisis, perancangan, dan pengkodean dari perangkat lunak itu sendiri. 
Tabel 1. Pengujian Sistem Informasi Rekam Medis Pada Praktek Dokter Hewan Nurcahyo Saksono Berbasis Web

\begin{tabular}{|c|c|c|c|}
\hline No & Kelas Uji & Pengujian & Kelayakan \\
\hline 1 & Registrasi & $\begin{array}{l}\text { Melakukan penginputan data pemilik hewan dan } \\
\text { tersimpan di database dan dapat } \\
\text { ditampilkan }\end{array}$ & Layak \\
\hline 2 & Login & $\begin{array}{l}\text { Melakukan login verifikasi username dan } \\
\text { password }\end{array}$ & Layak \\
\hline 3 & Pendaftaran rekam medis & $\begin{array}{l}\text { Melakukan penginputan pendaftaran rekam } \\
\text { medis, data tesimpan kedalam databse dan dapat } \\
\text { ditampilkan }\end{array}$ & Layak \\
\hline 4 & Data dokter & $\begin{array}{lll}\text { Melakukan } & \text { penginputandatadokter } & \text { dan } \\
\text { tersimpan } & \text { kedalam databse dan dapat } \\
\text { ditampilkan } & & \end{array}$ & Layak \\
\hline 5 & Data pasien & Menampilkan data pasien yang telah registrasi & Layak \\
\hline 6 & Data obat & $\begin{array}{llll}\text { Melakukan penginputan data obat dan } \\
\text { tersimpan kedalam databse } \\
\text { ditampilkan }\end{array}$ & Layak \\
\hline 7 & Data jenis pemeriksaan & $\begin{array}{l}\text { Melakukan penginputan data jenis } \\
\text { pemeriksaan dan tersimpan kedalam databse dan } \\
\text { dapat ditampilkan }\end{array}$ & Layak \\
\hline 8 & Data praktek Dokter & $\begin{array}{l}\text { Melakukan penginputan data praktek dokter dan } \\
\text { tersimpan kedalam databse dan dapat } \\
\text { ditampilkan }\end{array}$ & Layak \\
\hline 9 & Data pendaftaran & $\begin{array}{l}\text { Menampilkan data pendaftaran rekam medis } \\
\text { dan dapat dikonfirmasi staff administrasi }\end{array}$ & Layak \\
\hline 10 & Data penjadwalan & $\begin{array}{l}\text { Melakukan pemilihan jadwal pemeriksaan, apabila } \\
\text { jadwal benturan pemilik hewan harus } \\
\text { meilih jadwal lain yantersedia }\end{array}$ & layak \\
\hline 11 & Data rekam medis & Menampilkan data rekam medis & Layak \\
\hline 12 & Data konsultasi & Menampilkan data konsultasi & Layak \\
\hline 13 & Laporan rekam medis & $\begin{array}{l}\text { Melakukan rekap laporan per periode dan data } \\
\text { tampil }\end{array}$ & Layak \\
\hline
\end{tabular}

\section{KESIMPULAN}

Berdasarkan hasil implementasi system yang telah dilakukan maka dengan adanya sistem informasi rekam medis pada praktek dokter hewan Nurcahyo Saksono berbasis web dapat mempercepat proses administrasi dalam hal pendaftaran rekam medis, penjadwalan praktek dan konsultasi pemilik hewan yang dapat dilakukan secara online.tanpa harus datang. Dan dengan adanya sistem informasi rekam medis pada praktek dokter hewan Nurcahyo Saksono berbasis web dapat memudahkan pencarian data dan dokumen 
pemeriksaan, data pasien, data rekam medis ataupun data laporan per periode karena sudah tersimpan kedalam database dan dapat dikases dimanapun atau kapanpun.

\section{DAFTAR PUSTAKA}

Departemen Kesehatan RI. 2008. Keputusan Menteri Kesehatan RI Nomor 269/MENKES/SK/III/2008 Tentang Rekam Medis.(http://perpustakaan.depkes.go.id:8 180/bitstream/123456789/1310/1/PMK26 90308.pdf

George P. 2011. Sistem Informasi Managemen. (Terjemahan). Jakarta: Salemba Empat.

Kadir, Abdul. 2014. Pengenalan Sistem Informasi Edisi Revisi. Andi Offset, Yogyakarta. Raymond; Schell, Sidik. 2015. Pemrograman WEB dengan HTML. Bandung: Informatika Bandung. 